\title{
A new subspecies of Parnassius arcticus (Eisner, 1968) (Lepidoptera, Papilionidae) from the Momsky Range (Yakutia, Russia)
}

\author{
Roman V. Yakovlev ${ }^{1,2}$, Nazar A. Shapoval ${ }^{3}$, Yuri I. Bakhaev ${ }^{4}$, \\ Galina N. Kuftina ${ }^{3}$, Boris A. Khramov ${ }^{5}$
}

1 Altai State University, Lenina 61, Barnaul, 656049, Russia

2 Tomsk State University, Laboratory of Biodiversity and Ecology, Lenina pr. 36, 634050 Tomsk, Russia 3 Zoological Institute of the Russian Academy of Sciences, Universitetskaya nab. 1, St.-Petersburg, 199034, Russia

4 Telmana Street 21a-12, Lipetsk, 398002, Russia

5 Prazhskaya Street 9/2-13, St.-Petersburg, 192238, Russia

Corresponding author: Roman V. Yakovlev (e-mail: yakovlev_asu@mail.ru)

Academic editor: A. Matsyura | Received 1 July 2020 | Accepted 15 July 2020 | Published 28 August 2020

http://zoobank.org/BFB3B568-CAF3-4543-B9E6-7DA4A320F4AC

Citation: Yakovlev RV, Shapoval NA, Bakhaev YI, Kuftina GN, Khramov BA (2020) A new subspecies of Parnassius arcticus (Eisner, 1968) from the Momsky Range (Yakutia, Russia). Acta Biologica Sibirica 6: 93-105. https://doi.org/10.3897/abs.6.e55925

\begin{abstract}
On the basis of the characters of external morphology and analysis of DNA barcodes, an isolated population of the Arctic Apollo, Parnassius arcticus (Eisner, 1968) (Lepidoptera, Papilionidae), from the Momsky Range mountains (northeastern Yakutia, Russia) is described here as a new subspecies, Parnassius arcticus arbugaevi Yakovlev \& Shapoval, subsp. nov. The taxonomy, distribution, ecology, and biotopical preferences of the nominotypical P. arcticus and the new subspecies are discussed.
\end{abstract}

\section{Keywords}

Lepidoptera, Parnassiinae, Parnassius, DNA barcode, distribution, taxonomy.

Copyright Roman V. Yakovlev et al. This is an open access article distributed under the terms of the Creative Commons Attribution License (CC BY 4.0), which permits unrestricted use, distribution, and reproduction in any medium, provided the original author and source are credited. 


\section{Introduction}

The Arctic Apollo, Parnassius arcticus was described by Eisner (1968) and was erroneously attributed to $P$. simo Gray, 1853 as a subspecies (Tadumia simo arctica in the original description).

Subsequently, Eisner (1976) corrected this mistake and regarded P. arcticus as a subspecies of $P$. tenedius (Eversmann, 1851). The description was based on the two specimens from "den Bergen östlich von Werchnosensk" [sic!] ("Werchnosensk" should refer to Verkhoyansk, Yakutia, Russia). Later, a remote population from Suntar-Khayata was discovered and described by Korshunov (1988) as a separate species P. ammosovi Korshunov, 1988 (type locality - "Russia, Yakutia, Suntar-Khayata Range, $180 \mathrm{~km}$ ENE from the Khandyga settlement, river Vostochnaya Khandyga upper flow, 232nd $\mathrm{km}$ of the road from Khandyga to Magadan"). The status of $P$. ammosovi appears questionable for being of specific or subspecific rank. This taxon has also been occasionally treated as a synonym of $P$. arcticus (Gorbunov 2001; Gorbunov and Kosterin 2003). There are no clear morphological differences that distinguish $P$. ammosovi from $P$. arcticus including any obvious biogeographical barriers that could isolate these taxa.

The Arctic Apollo is known from the following localities, according to the contemporary data (Fig. 1) (Korshunov 1988; Chichvarkhin 2004; Gorbunov 2008; Bakhaev 2017):

1. Russia, Yakutia, Verkhoyansk range, river Kele headwater, river Kokchin (L. Popova leg.) - one specimen in ISEA collection.

2. Russia, Yakutia, Suntar-Khayata Range, $180 \mathrm{~km}$ ENE from the Khandyga vill., river Vostochnaya Khandyga upper flow, Khandyga-Magadan road, 1400-1450 $\mathrm{m}$ (type locality).

3. Russia, Yakutia, Suntar-Khayata Range, ca. $95 \mathrm{~km}$ WSW from the Kyubeme vill., $62^{\circ} 45^{\prime} 35^{\prime \prime} \mathrm{N}, 139^{\circ} 23^{\prime} 09^{\prime \prime} \mathrm{E}$.

4. Russia, Yakutia, Suntar-Khayata Range, $50 \mathrm{~km} \mathrm{~S}$ from Labynkyr lake, NE Yakutia, $62^{\circ} 09^{\prime} 00^{\prime \prime} \mathrm{N}, 143^{\circ} 26^{\prime} 40^{\prime \prime} \mathrm{E}, 1150-1200 \mathrm{~m}$.

5. Russia, Magadan, Kolyma highlands, Yablonovy pass, Khasyn distr. $\left[\sim 60^{\circ} 25^{\prime} \mathrm{N}, 151^{\circ} 13^{\prime} \mathrm{E}\right]$. A single specimen was collected by V. Baglikov (Gorbunov 2008).

It should be noted that the numerous attempts to find P. arcticus in the vicinity of Yablonovy Pass between 1995-1999 have not been successful, thus the presence of the species in Magadan Region requires confirmation.

The biology of the $P$. arcticus has been described in detail by several authors (Popova 1988; Glushchenko 1996; Gorbunov and Kosterin 2003; Vinokurov and Stepanov 2007; Bakhaev 2017). This taxon inhabits scree mountain slopes of southern and south-western exposition at altitudes of 1200-1700 m, and apparently 
occurs in low number of individuals. Adults are feeding on Gorodkovia jacutica Botschantzev \& Karavaev, 1959 (Brassicaceae) and ignore other flowering plants. Females oviposit on stones near the larval hostplant, Corydalis gorodkovii Karavaev 1957 (Papaveraceae), or at the bottom of the plant stem. The pupa is the overwintering stage. Butterflies fly from early June (rare from late May) to the beginning of July and in some years into the middle of July.

Recent phylogenetic studies revealed $P$. arcticus together with $P$. tenedius form the most basal, strongly differentiated lineage of Parnassius sensu lato, supporting its placement within the separate (sub) genus Sachaia (Michel et al. 2008; Zheng et al. 2018). It should be noted that despite dissimilarities in the sphragis and genitalia morphology as well as pronounced differences in size, wing pattern, habitat choices and food plants, these taxa appeared to be similar genetically. The phylogenetic reconstructions based on four genes (mitochondrial ND5, COI; nuclear Wingless, EF1- $\alpha$ ) demonstrates lack of significant genetic differentiation between P. arcticus and P. tenedius (Omoto et al. 2004; Chichvarkhin et al. 2004). This fact led to the assumption on the conspecificity of this pair of taxa, but further research based on additional material is needed to fully clarify this conclusion. The phylogenetic relationships of $P$. arcticus and $P$. tenedius are not analyzed nor discussed in detail here because of a different focus of our article and the limited number of sequenced samples currently available.

During the field trip to northeastern Yakutiya taken in 2019, a remote population of P. arcticus from the Momsky Range was discovered and the analyses of DNA barcodes and morphological traits (genitalia, wing pattern) were performed. Herein we present the results of these studies, and describe a distinctive Yakutian population of Arctic Apollo as a new subspecies, P. arcticus arbugaevi ssp. $\mathbf{n}$.

\section{Material and methods}

\section{Taxon sampling}

Butterflies for the present study were collected in Yakutia on the Suntar-Khayata and the Momsky Ranges by B. Khramov and Yu. Bakhaev during the field expeditions in 1991 and 2017-2019 (list of collected specimens is given in Table 1).

\section{Genitalia dissection and imaging}

Male genitalia were mounted in euparal on slides following Lafontain and Mikkola (1987) and examined with an Olympus SZX16 microscope. The images were taken with the Olympus SZX16 camera. The images were processed using Adobe Photoshop CC software. 


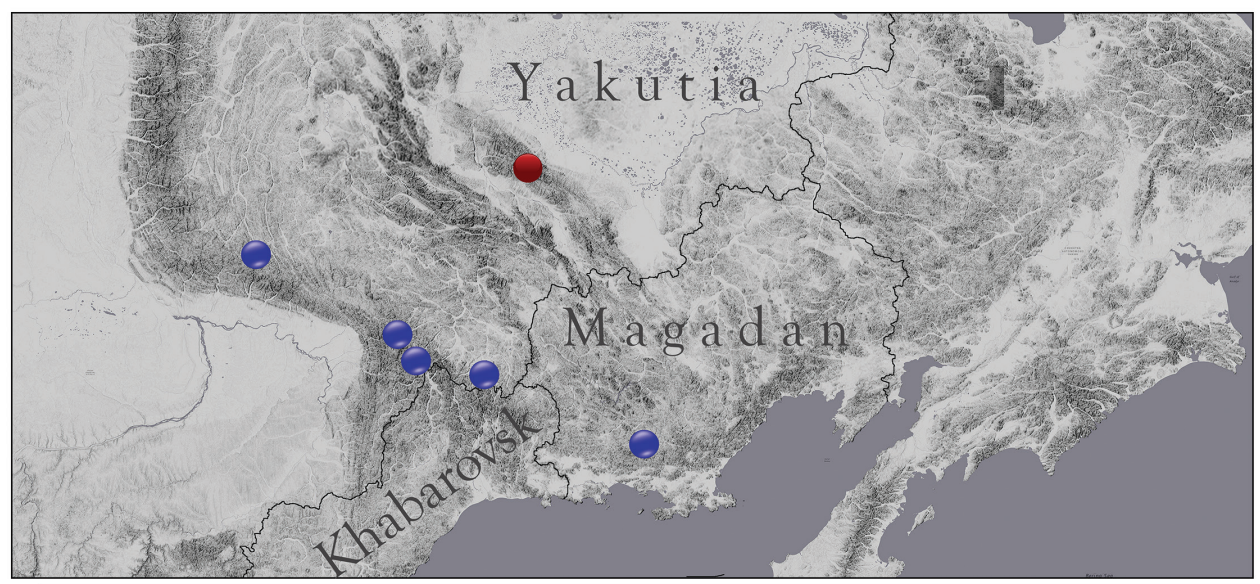

Figure 1. Map of collecting localities of Parnassius arcticus: blue circles - P. a. arcticus, red circle $-P$. a. arbugaevi ssp. n.

\section{DNA extraction and sequencing}

One leg from each specimen was taken for DNA extraction using QIAamp DNA Investigator Kit (Qiagen, Netherlands) following the manufacturer's protocol. Standard DNA-barcode (658 bp fragment of the mitochondrial cytochrome oxidase subunit I gene $(C O I)$ ) was used as a molecular marker. COI barcodes were analysed using approaches described previously (Shapoval et al. 2017; Yakovlev et al. 2018). Sequencing of the

Table 1. List of studied material

\begin{tabular}{|c|c|c|c|}
\hline Species & Sex & GenBank No & Locality \\
\hline P. arcticus arcticus & $\mathrm{F}$ & - & $\begin{array}{l}\text { Russia, Yakutia, Suntar-Khayata Range, Vostochnaya } \\
\text { Khandyga riv., Khandyga-Magadan rd., Sukhaya } \\
\text { Rechka riv., } 63^{\circ} 07^{\prime} 31^{\prime N} \text {, } 138^{\circ} 58^{\prime} 33^{\prime \prime E}, \mathrm{~h}=1400 \mathrm{~m}, 10- \\
\text { 20.06.1991, leg. B. Khramov }\end{array}$ \\
\hline P. arcticus arcticus & $\mathrm{F}$ & - & $\begin{array}{l}\text { Russia, Yakutia, Suntar-Khayata Range, Vostochnaya } \\
\text { Khandyga riv., Khandyga-Magadan rd., Sukhaya } \\
\text { Rechka riv., } 63^{\circ} 07^{\prime} 31^{\prime N} \text { N, } 138^{\circ} 58^{\prime} 33^{\prime E} \mathrm{E} \text { h=1400 m, 10- } \\
\text { 20.06.1991, leg. B. Khramov }\end{array}$ \\
\hline P. arcticus arcticus & $\mathrm{F}$ & - & $\begin{array}{l}\text { Russia, Yakutia, Suntar-Khayata Range, Vostochnaya } \\
\text { Khandyga riv., Khandyga-Magadan rd., Sukhaya } \\
\text { Rechka riv., } 63^{\circ} 07^{\prime} 31^{\prime \prime N}, 138^{\circ} 58^{\prime} 33^{\prime E} \text {, h=1400 m, 10- } \\
\text { 20.06.1991, leg. B. Khramov }\end{array}$ \\
\hline P. arcticus arcticus & $\mathrm{F}$ & - & $\begin{array}{l}\text { Russia, Yakutia, Suntar-Khayata Range, Vostochnaya } \\
\text { Khandyga riv., Khandyga-Magadan rd., Sukhaya } \\
\text { Rechka riv., } 63^{\circ} 07^{\prime} 31^{\prime N} \mathrm{~N}, 138^{\circ} 58^{\prime} 33^{\prime} \mathrm{E}, \mathrm{h}=1400 \mathrm{~m}, 10- \\
\text { 20.06.1991, leg. B. Khramov }\end{array}$ \\
\hline P. arcticus arcticus & M & - & $\begin{array}{l}\text { R Russia, Yakutia, Suntar-Khayata Range, Vostochnaya } \\
\text { Khandyga riv., Khandyga-Magadan rd., Sukhaya } \\
\text { Rechka riv., } 63^{\circ} 07^{\prime} 31^{\prime N} \text {, } 138^{\circ} 58^{\prime} 33^{\prime \prime E}, \mathrm{~h}=1400 \mathrm{~m}, 10- \\
\text { 20.06.1991, leg. B. Khramov }\end{array}$ \\
\hline
\end{tabular}




\begin{tabular}{|c|c|c|c|}
\hline Species & Sex & GenBank No & Locality \\
\hline P. arcticus arcticus & M & - & $\begin{array}{l}\text { Russia, Yakutia, Suntar-Khayata Range, Vostochnaya } \\
\text { Khandyga riv., Khandyga-Magadan rd., Sukhaya } \\
\text { Rechka riv., } 63^{\circ} 07^{\prime} 31^{\prime N}, 138^{\circ} 58^{\prime} 33^{\prime E} \mathrm{E}, \mathrm{h}=1400 \mathrm{~m}, 10- \\
\text { 20.06.1991, leg. B. Khramov }\end{array}$ \\
\hline$P$. arcticus arcticus & M & - & $\begin{array}{l}\text { Russia, Yakutia, Suntar-Khayata Range, Vostochnaya } \\
\text { Khandyga riv., Khandyga-Magadan rd., Sukhaya } \\
\text { Rechka riv., } 63^{\circ} 07^{\prime} 31^{\prime N} \text {, } 138^{\circ} 58^{\prime} 33^{\prime E} \mathrm{E}, \mathrm{h}=1400 \mathrm{~m}, 10- \\
\text { 20.06.1991, leg. B. Khramov }\end{array}$ \\
\hline P. arcticus arcticus & M & - & $\begin{array}{l}\text { Russia, Yakutia, Suntar-Khayata Range, Vostochnaya } \\
\text { Khandyga riv., Khandyga-Magadan rd., Sukhaya } \\
\text { Rechka riv., 630' } 31^{\prime \prime N, ~} 138^{\circ} 58^{\prime} 33^{\prime E} \text {, h=1400 m, 10- } \\
\text { 20.06.1991, leg. B. Khramov }\end{array}$ \\
\hline$P$. arcticus arcticus & M & - & $\begin{array}{l}\text { Russia, Yakutia, Suntar-Khayata Range, ca. } 95 \mathrm{~km} \\
\text { WSW from the Kyubeme vill., } 62^{\circ} 45^{\prime} 35^{\prime \prime N}, 139^{\circ} 23^{\prime} 09^{\prime \prime} \mathrm{E} \text {, } \\
\text { 13.06.2017, leg. Yu. Bakhaev }\end{array}$ \\
\hline P. arcticus arcticus & M & - & $\begin{array}{l}\text { Russia, Yakutia, Suntar-Khayata Range, ca. } 95 \mathrm{~km} \text { WSW } \\
\text { from the Kyubeme vill., } 62^{\circ} 45^{\prime} 35^{\prime \prime N}, 139^{\circ} 23^{\prime} 09^{\prime \prime} \mathrm{E}, 10- \\
15.06 .2018 \text {, leg. Yu. Bakhaev }\end{array}$ \\
\hline P. arcticus arcticus & M & MT741524 & $\begin{array}{l}\text { Russia, Yakutia, Suntar-Khayata Range, ca. } 95 \mathrm{~km} \text { WSW } \\
\text { from the Kyubeme vill., } 62^{\circ} 45^{\prime} 35^{\prime \prime N}, 139^{\circ} 23^{\prime} 09^{\prime \prime} \mathrm{E}, 10- \\
15.06 .2018 \text {, leg. Yu. Bakhaev }\end{array}$ \\
\hline P. arcticus arcticus & M & MT741525 & $\begin{array}{l}\text { Russia, Yakutia, Suntar-Khayata Range, ca. } 95 \mathrm{~km} \text { WSW } \\
\text { from the Kyubeme vill., } 62^{\circ} 45^{\prime} 35^{\prime \prime N}, 139^{\circ} 23^{\prime} 09^{\prime \prime} \mathrm{E}, 10- \\
15.06 .2018 \text {, leg. Yu. Bakhaev }\end{array}$ \\
\hline P. arcticus arcticus & M & MT741526 & $\begin{array}{l}\text { Russia, Yakutia, Suntar-Khayata Range, ca. } 95 \mathrm{~km} \text { WSW } \\
\text { from the Kyubeme vill., } 62^{\circ} 45^{\prime} 35^{\prime \prime N}, 139^{\circ} 23^{\prime} 09^{\prime \prime} \mathrm{E}, 10- \\
15.06 .2018 \text {, leg. Yu. Bakhaev }\end{array}$ \\
\hline P. arcticus arbugaevi & $\mathrm{F}$ & - & $\begin{array}{l}\text { Russia, NE Yakutia, Momsky Range, } 70 \mathrm{~km} \text { E of } \\
\text { Khonuu village, } 1400 \mathrm{~m}, 22-24.06 .2019 \text {, leg. Yu. } \\
\text { Bakhaev }\end{array}$ \\
\hline P. arcticus arbugaevi & $\mathrm{F}$ & - & $\begin{array}{l}\text { Russia, NE Yakutia, Momsky Range, } 70 \mathrm{~km} \text { E of } \\
\text { Khonuu village, } 1400 \mathrm{~m}, 22-24.06 .2019 \text {, leg. Yu. } \\
\text { Bakhaev }\end{array}$ \\
\hline P. arcticus arbugaevi & $\mathrm{F}$ & - & $\begin{array}{l}\text { Russia, NE Yakutia, Momsky Range, } 70 \mathrm{~km} \text { E of } \\
\text { Khonuu village, } 1400 \mathrm{~m}, 22-24.06 .2019 \text {, leg. Yu. } \\
\text { Bakhaev }\end{array}$ \\
\hline P. arcticus arbugaevi & M & MT741527 & $\begin{array}{l}\text { Russia, NE Yakutia, Momsky Range, } 70 \text { km E of } \\
\text { Khonuu village, } 1400 \text { m, 22-24.06.2019, leg. Yu. } \\
\text { Bakhaev }\end{array}$ \\
\hline P. arcticus arbugaevi & M & MT741528 & $\begin{array}{l}\text { Russia, NE Yakutia, Momsky Range, } 70 \mathrm{~km} \text { E of } \\
\text { Khonuu village, } 1400 \text { m, 22-24.06.2019, leg. Yu. } \\
\text { Bakhaev }\end{array}$ \\
\hline P. arcticus arbugaevi & M & MT741529 & $\begin{array}{l}\text { Russia, NE Yakutia, Momsky Range, } 70 \mathrm{~km} \text { E of } \\
\text { Khonuu village, } 1400 \mathrm{~m}, 22-24.06 .2019 \text {, leg. Yu. } \\
\text { Bakhaev }\end{array}$ \\
\hline P. arcticus arbugaevi & M & - & $\begin{array}{l}\text { Russia, NE Yakutia, Momsky Range, } 70 \mathrm{~km} \text { E of } \\
\text { Khonuu village, } 1400 \mathrm{~m}, 22-24.06 .2019 \text {, leg. Yu. } \\
\text { Bakhaev }\end{array}$ \\
\hline P. arcticus arbugaevi & M & - & $\begin{array}{l}\text { Russia, NE Yakutia, Momsky Range, } 70 \text { km E of } \\
\text { Khonuu village, } 1400 \text { m, 22-24.06.2019, leg. Yu. } \\
\text { Bakhaev }\end{array}$ \\
\hline
\end{tabular}




\begin{tabular}{|c|c|c|c|}
\hline Species & Sex & GenBank No & Locality \\
\hline P. arcticus arbugaevi & $\mathrm{M}$ & - & $\begin{array}{l}\text { Russia, NE Yakutia, Momsky Range, } 70 \mathrm{~km} \text { E of } \\
\text { Khonuu village, } 1400 \mathrm{~m}, 22-24.06 .2019 \text {, leg. Yu. } \\
\text { Bakhaev }\end{array}$ \\
\hline P. arcticus arbugaevi & M & - & $\begin{array}{l}\text { Russia, NE Yakutia, Momsky Range, } 70 \mathrm{~km} \text { E of } \\
\text { Khonuu village, } 1400 \mathrm{~m}, 22-24.06 .2019 \text {, leg. Yu. } \\
\text { Bakhaev }\end{array}$ \\
\hline P. arcticus arbugaevi & M & - & $\begin{array}{l}\text { Russia, NE Yakutia, Momsky Range, } 70 \mathrm{~km} \text { E of } \\
\text { Khonuu village, } 1400 \mathrm{~m}, 22-24.06 .2019 \text {, leg. Yu. } \\
\text { Bakhaev }\end{array}$ \\
\hline P. arcticus arbugaevi & M & - & $\begin{array}{l}\text { Russia, NE Yakutia, Momsky Range, } 70 \mathrm{~km} \text { E of } \\
\text { Khonuu village, } 1400 \mathrm{~m}, 22-24.06 .2019 \text {, leg. Yu. } \\
\text { Bakhaev }\end{array}$ \\
\hline P. arcticus arbugaevi & M & - & $\begin{array}{l}\text { Russia, NE Yakutia, Momsky Range, } 70 \mathrm{~km} \text { E of } \\
\text { Khonuu village, } 1400 \mathrm{~m}, 22-24.06 .2019 \text {, leg. Yu. } \\
\text { Bakhaev }\end{array}$ \\
\hline P. arcticus arbugaevi & M & - & $\begin{array}{l}\text { Russia, NE Yakutia, Momsky Range, } 70 \text { km E of } \\
\text { Khonuu village, } 1400 \text { m, 22-24.06.2019, leg. Yu. } \\
\text { Bakhaev }\end{array}$ \\
\hline P. arcticus arbugaevi & M & - & $\begin{array}{l}\text { Russia, NE Yakutia, Momsky Range, } 70 \mathrm{~km} \text { E of } \\
\text { Khonuu village, } 1400 \mathrm{~m}, 22-24.06 .2019 \text {, leg. Yu. } \\
\text { Bakhaev }\end{array}$ \\
\hline
\end{tabular}

double-stranded product was carried out at the Research Resource Center for Molecular and Cell Technologies (Saint-Petersburg State University). DNA barcodes from a total of six individuals (three specimens of the nominotypical P. arcticus from SuntarKhayata, and three specimens of P. arcticus arbugaevi from the Momsky Range) were sequenced for the present study (Table 1). We also included two sequences of $P$. arcticus specimens deposited in GenBank under accession numbers EF473826 and AM231434.

\section{List of abbreviations}

ZISP Zoological Institute (St.-Petersburg, Russia)

ISEA Institute of Systematic and Ecology of Animals (Novosibirsk, Russia)

\section{Results and discussion}

Sequencing of three specimens from the Suntar-Khayata Range and three samples from the Momsky Range performed in the current study did not reveal intra-population polymorphism, all of the sequenced specimens share one COI haplotype within certain population. At the same time, specimens from the Momsky Range differs from the Suntar-Khayata specimens by two fixed synonymous nucleotide substitutions $(A \rightarrow G)$ in positions 412 and 511 of the COI DNA barcode (Fig. 2). Chichvarkhin (2004) analysed $P$. arcticus from two remote populations at a distance of ca. $240 \mathrm{~km}$ of the Suntar-Khayata range. All 20 examined specimens appeared to be genetically homogenous with respect to studied mitochondrial and nuclear 
genes. Unfortunately, these sequences are not publicly accessible and, therefore, cannot be compared with our data.

Taking into account the low genetic differentiation observed between $P$. tenedius and $P$. arcticus, as well as the absence of intra-population polymorphism within $P$. arcticus, revealed fixed differences in the COI gene between $P$. $a$. arcticus and the newly discovered population, $P$. a. arbugaevi ssp.n., may reflect a relatively old isolation of the Momsky Range and the Suntar-Khayata populations due to a fragmentation of the original ancestral range of the taxon. Both subspecies have similar ecological preferences, occupying almost devoid of vegetation black aleurolite screes above $1000 \mathrm{~m}$ a.s.l., and being a strict host-specialists, feeding on only one Corydalis species (Fig. 6). The new subspecies also did not show significant differences in the male genitalia (Fig. 3), while differs considerably in the wing shape and wing pattern (mainly by the absence of dark spot in the forewing discal cell), which especially distinct in the females (Figs 4-5).

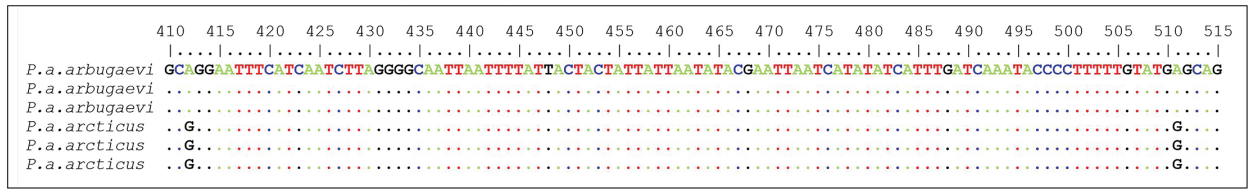

Figure 2. Nucleotide differences between Parnassius arcticus arcticus and P. arcticus arbugaevi ssp. n. within studied $658 \mathrm{bp}$ fragment of COI gene.

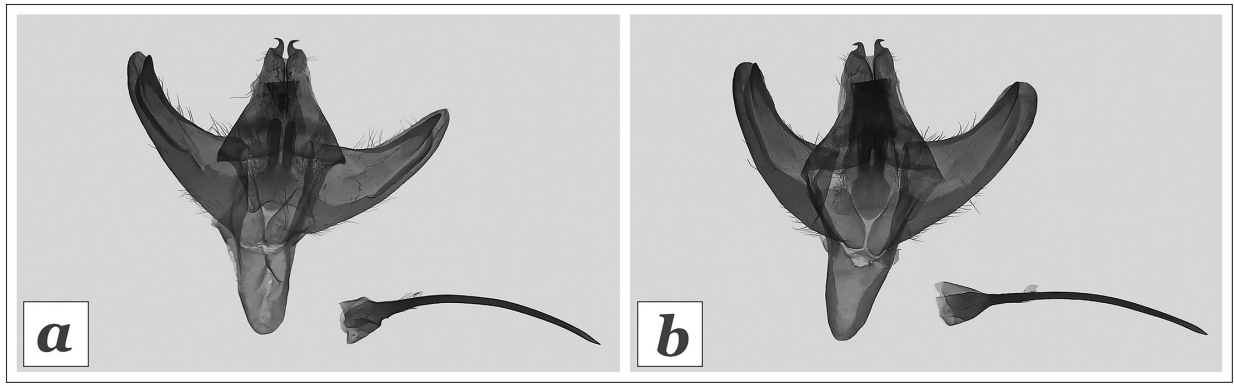

Figure 3. Male genitalia of Parnassius arcticus: a - P. a. arcticus (slide coll. Yakovlev 2020\#6); b - P. a. arbugaevi ssp. n. (slide coll. Yakovlev 2020\#8).

\section{Description of the new subspecies}

Parnassius arcticus arbugaevi Yakovlev \& Shapoval, subsp. nov. http://zoobank.org/37017492-ba4e-4c0f-8186-2e291d00ca9f

Figs 1, 3, 4, 6

Holotype. $\hat{\delta}$. Wingspan $45 \mathrm{~mm}$. Russia, North-Eastern Yakutia, Momsky District, $70 \mathrm{~km}$ E of Khonuu village, 1400 m, 22-24.06.2019, leg. Yu. Bakhaev, deposited in the Zoological Institute of the Russian Academy of Sciences (St. Petersburg). 


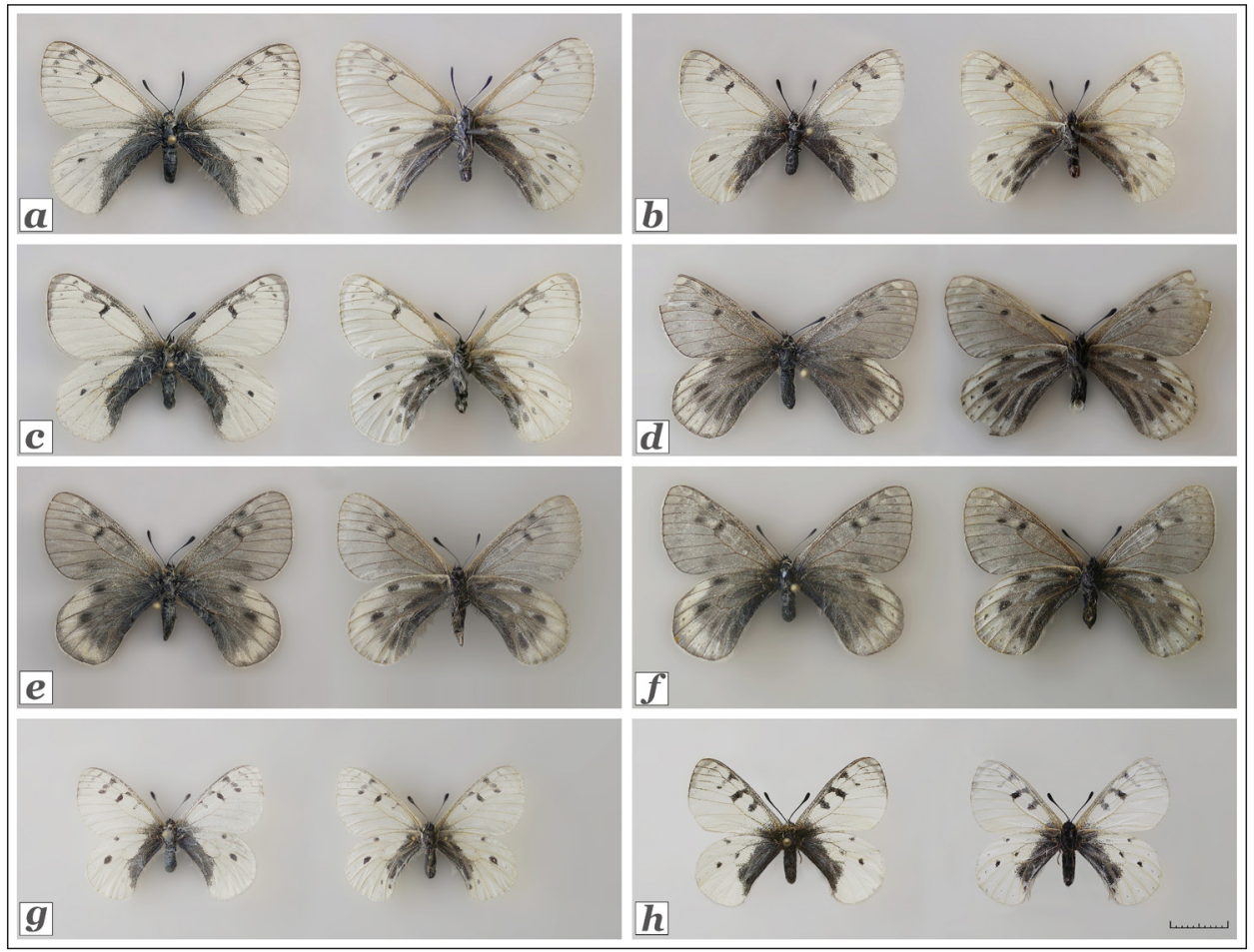

Figure 4. Wing pattern of Parnassius arcticus arbugaevi ssp. n. (a-f) and P. arcticus arcticus (g-h): a - male, holotype; b-c - males, paratypes; d-f - females, paratypes; [Russia, NE Yakutia, Momsky Range, 70 km E of Khonuu village, 1400 m, 22-24.06.2019, leg. Yu. Bakhaev]; g-h - males, [Russia, NE Yakutia, Suntar-Khayata Range, ca. 95 km WSW from the Kyubeme vill., 13.06.2017 (g), 10-15.06.2018 (h), leg. Yu. Bakhaev]. Scale bar $=1 \mathrm{~cm}$.

Paratypes. 11 성 and 3 우우, the same locality, date and collector as the holotype. Paratypes deposited in the ZISP (one female) and private collections of Roman Yakovlev (three males) and Yu. Bakhaev (eight males and two females).

Description. Males. Wingspan 39-45 mm. Body and antennae black.

Forewing. Upperside white, with semi-transparent apex, small black blurred submarginal spots between veins R2+3-R4-R5-M1-M2, and small black blurred posdiscal spots in cells $\mathrm{R} 2+3-\mathrm{R} 4+5-\mathrm{M} 1$; fringe white; border black; discal spot black; basal area and costa with noticeable sputtering of black scales. Underside white, pattern similar to forewing upperside.

Hindwing. Upperside white, with small poorly noticeable black spot in cell $\mathrm{Sc}+\mathrm{R}-\mathrm{Rs}$ and distinct black spot in cell M1-M2; wing base and anal areas heavily blackened; fringe white with border brownish. Underside white, with distinct black pattern, prominent dark-grey spot in cell $\mathrm{Sc}+\mathrm{R}$-Rs and longitudinal black strokes in cells M3-Cu1-Cu2-2A; basal area with poorly noticeable blurred ochre-red strokes. 


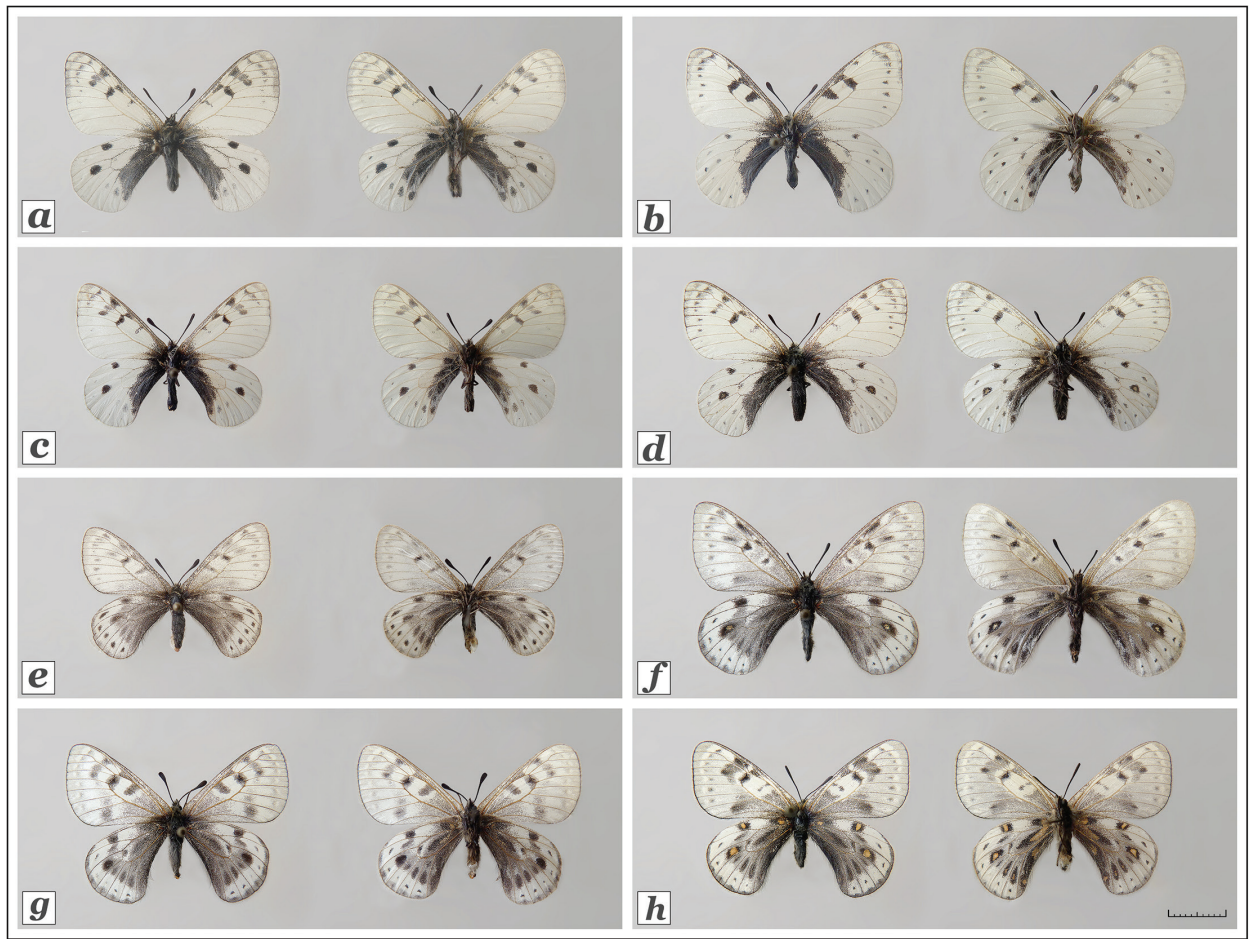

Figure 5. Wing pattern of Parnassius arcticus arcticus: a-d - males; e-h - females; [Russia, Yakutia, Suntar-Khayata Range, Vostochnaya Khandyga riv., Khandyga-Magadan rd., Sukhaya Rechka riv., h=1400 m, 10-20.06.1991, leg. B. Khramov]. Scale bar $=1 \mathrm{~cm}$.

Variability. Forewing black spots between veins R2+3-R4-R5-M1-M2 submarginally reduced in one specimen; in several males red pattern on wing underside completely reduced.

Females. Wingspan 43-46 mm. Body and antennae black.

Forewing. Upperside smoky-black with poorly expressed cream fields in apical part and slight sputtering of cream scales throughout wing (especially in discal cell), series of slightly noticeable dark submarginal spots and large black blurred posdical spots in cells R2+3-R4+5-M1; discal spot large, black. Underside paler than upperside, slight sputtering of cream scales, pattern similar to upperside.

Hindwing. Upperside black with wide, light-cream submarginal band and distinct large black spots in cells Sc+R-Rs and M1-M2. Underside paler than upperside, pattern similar to upperside, but with slightly expressed series of black spots in submarginal light band; slight ocher strokes in dark spots in cells Sc+R-Rs and M1-M2; slight ocher pattern at base of wing.

Variability. The ocher pattern on hindwing underside completely reduced in two individuals; in one female, longitudinal black strokes present in cells M3-Cu1$\mathrm{Cu} 2-2 \mathrm{~A}$ on hindwing underside. 

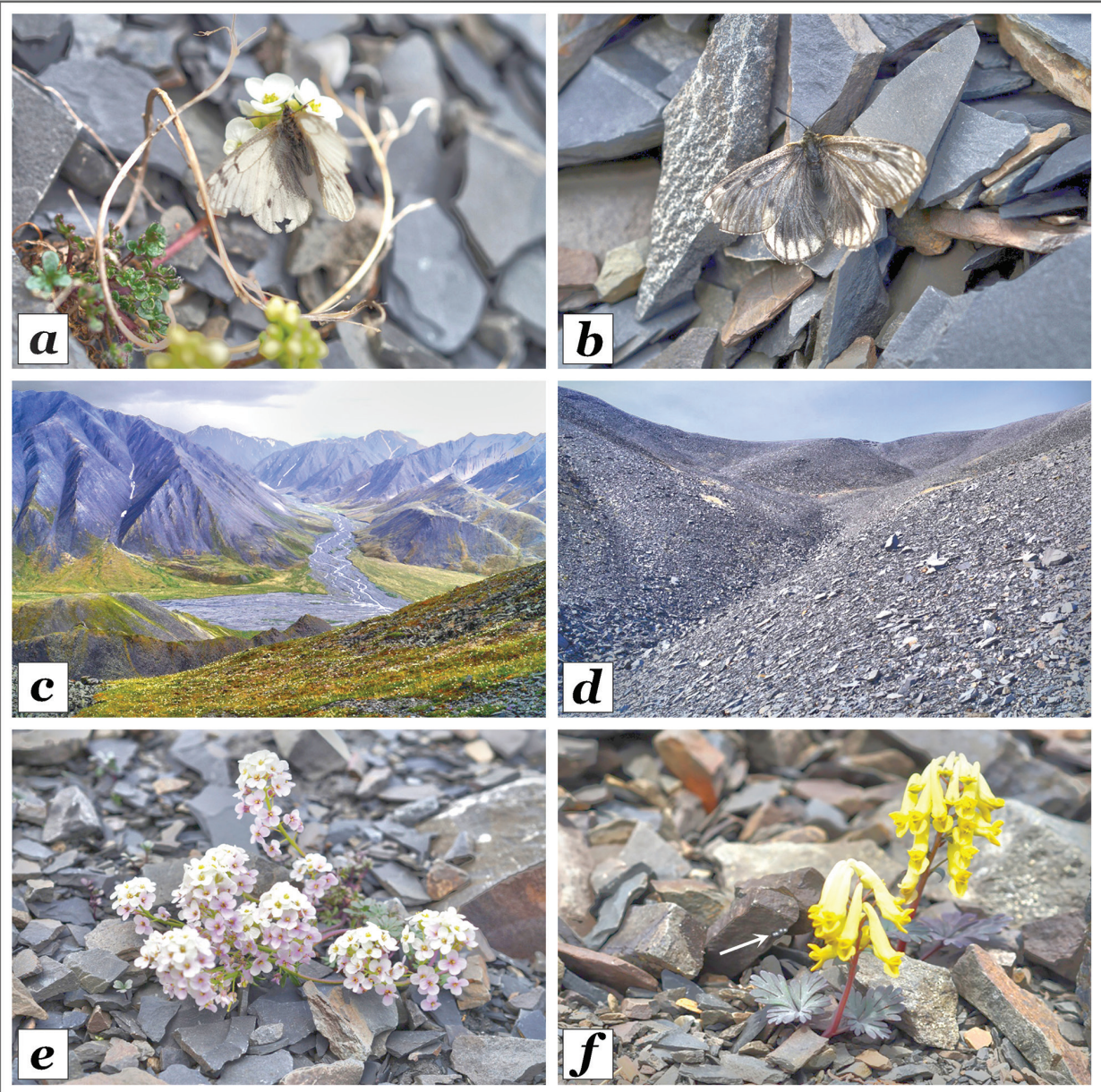

Figure 6. Parnassius arcticus arbugaevi, adult specimens in nature, host plants and habitat (photo by Yu. Bakhaev): a, b - P. a. arbugaevi ssp.n. in nature, male and female; $\mathbf{c}, \mathbf{d}-$ habitat of $P$. a. arbugaevi; $\mathbf{e}$ - Gorodkovia jacutica, feeding plant of adults of $P$. a. arbugaevi; $\mathbf{f}-$ Corydalis gorodkovii - larval host plant of $P$. a. arbugaevi. Location of eggs laid on stones near the larval hostplant indicated by an arrow.

Genitalia. Male genitalia is similar to the nominotypical $P$. arcticus (Fig. 3). Uncus forked, short, with uncinate apices diverged to sides; valve cup-like, with even edges, apically semicircular; conical harpe on inner surface of valve, slightly protruding beyond the apex of valve; juxta oval, with pair of flask-shaped processes directed dorsally; saccus robust, conical; phallus thin, slightly curved along all length, apically needle-like, 1/3 longer than valve.

Diagnosis. From the nominotypical $P$. arcticus the new subspecies can be distinguished by more elongated wings; the absence of dark spot in the discal cell in 
both males and females (P. a. arcticus has a more or less expressed black spot, especially distinct in females); the occasional presence of slightly noticeable blurred ochre-red strokes at the hindwing base; almost unicolorous, with poorly expressed pattern, forewing underside of females (in $P$. a. arcticus the wing is mottled, with alternating light and dark elements); the entirely black distinct spots on hindwing upperside of females in cells $\mathrm{Sc}+\mathrm{R}-\mathrm{Rs}$ and $\mathrm{M} 1-\mathrm{M} 2$ (in $P$. a. arcticus often the black spots have red centres). The new subspecies on an average is larger in size: male wingspan is $39-45 \mathrm{~mm}$, females - $43-46 \mathrm{~mm}$ (in P. arcticus: $32-41 \mathrm{~mm}$ and $37-40$ $\mathrm{mm}$, respectively). Genetically, $P$. a. arbugaevi differs by two fixed substitutions from nominotypical $P$. arcticus within the studied $658 \mathrm{bp}$ fragment of the mitochondrial gene COI.

Ecology. The new subspecies inhabits dry scree slopes with poor vegetation at an elevation of $1400 \mathrm{~m}$ (Fig. 6c-d). Adults nectar on Gorodkovia jacutica. Females were observed to oviposit on stones near the larval hostplant (Fig. 6f), Corydalis gorodkovii, the same as for nominative subspecies.

Distribution. Known only from the type locality (Momsky Range, NE Yakutia).

Etymology. The new subspecies is named after German Arbugaev (Yakutsk), who provided comprehensive assistance to the entomological research of Yu.I. Bakhaev in Yakutia.

\section{Acknowledgements}

The authors are grateful to all the colleagues whom provided assistance in preparing the article. Andrei Barabanov, Anatoly Krupitsky and Zdenek Faltynek Fric gave valuable comments, Ilya Yudakov allowed us to use P. arcticus image from his private collection, Boris Anokhin helped with images preparation. In organizing the field studies, an invaluable assistance was provided by the director of Momsky Natural Park, Mikhail Ivanov, inspector Innokentiy Fedorov, the director of ecological-ethnographic complex "Chochur Muran" German Arbugaev. The assistance in finding the comparative material and inaccessible publications was provided by Alexander Streltsov. The genital slides were made by Ksenia Proskuryakova. The financial support for this study was provided to N. Shapoval by the grant N 19-1400202 from the Russian Science Foundation to the Zoological Institute of the Russian Academy of Sciences.

\section{Authors contribution}

R.V. Yakovlev and N.A. Shapoval contributed equally to the study design, analysis and manuscript preparation. 


\section{References}

Bakhaev Y (2017) Notes on the biology of Arctic Apollo Parnassius arcticus (Eisner, 1968) in Yakutia (Lepidoptera, Papilionidae). Atalanta 48 (1-4): 170-173.

Chichvarkhin A (2004) Molecular phylogeny of Parnassian butterflies of the (sub) genus Sachaia Korshunov, 1986: Unexpectedly low generic divergence sheds light to their systematics and evolution. Wallace 9: 25-29.

Eisner C (1968) Parnassiana Nova. XLIII. Nachträgliche Betrachtungen zu der Revision der Subfamilie Parnassiinae (Fortsetzung 16). Zoologische Mededelingen 43 (2): 9-17.

Eisner C (1976) Parnassiana Nova. XLIX. Die Arten und Unterarten der Parnassidae (Lepidoptera) (Zweiter Teil). Zoologische Verhandelingen 146 (1): 99-259

Glushchenko YN (1996) Materials for investigation of Papilionid Butterflies of North-Eastern Yakutia. Natural Sciences and education in southern Far East 1:29-41. [in Russian].

Gorbunov PY (2001) The butterflies of Russia: classification, genitalia, keys for identification (Lepidoptera: Hesperiidea and Papilionoidea). Thesis, Ekaterinburg, 320 pp.

Gorbunov PY (2008) 3. Apollon arctichesky. In: Chereshnev IA (Ed.) Red Data Book of Magadan Region. Administration of Magadan Region, Department of natural resources; Institute of Biological problems of North, Magadan, 30-31. [in Russian].

Gorbunov PY, Kosterin OE (2003) The Butterflies (Hesperioidea and Papilionoidea) of North Asia (Asian part of Russia) in Nature. Vol. 1. Rodina \& Fodio and Gallery Fund, Moscow-Chelyabinsk, 392 pp.

Korshunov YP (1988) New butterflies (Lepidoptera, Rhopalocera) from Khakasia, Tuva and Yakutia. In: Zolotarenko GS (Ed.) Taxonomy of animals of Siberia, Nauka, Novosibirsk, 65-80. [in Russian].

Lafontaine JD, Mikkola K (1987) Lock-and-key system in the inner genitalia of Noctuidae(Lepidoptera) as taxonomic character. Entomologiske Meddelelser 55: 161-167.

Michel F, Rebourg C, Cosson E, Descimon H (2008) Molecular phylogeny of Parnassiinae butterflies (Lepidoptera: Papilionidae) based on the sequences of four mitochondrial DNA segment. Annales de la Société entomologique de France (N.S.) 44(1): 1-36. https://doi.org/10.1080/00379271.2008.10697541

Omoto K, Katoh T, Chichvarkhin A, Yagi T (2004) Molecular systematics and evolution of the "Apollo" butterflies of the genus Parnassius (Lepidoptera: Papilionidae) based on mitochondrial DNA sequence data. Gene 326: 141-147. https://doi.org/10.1016/j. gene.2003.10.020

Popova LI (1988) The Butterflies (Lepidoptera, Diurna) of Suntar-Khayata Range (Eastern Yakutia). In: Revin YV (Ed.) Insects of meadow-taiga biocenoses of Yakutia. Yakutian branch of Siberian Division of Academy of sciences of USSR, Yakutsk, 68-77. [In Russian].

Shapoval NA, Yakovlev RV, Kuftina GN (2017) The taxonomic status of Cossus cossus afghanistanus (Lepidoptera, Cossidae) from Afghanistan: insights from molecular and morphological data. Ukrainian Journal of Ecology 7 (3): 134-138. https://doi. org/10.15421/2017_61 
Vinokurov NN, Stepanov AD (2007) On population density of Parnasssius arcticus ammosovi Korsh. (Lepidoptera, Papilionoidea) in Suntar-Khayata Mountains. Diversity of insects and spiders at the specially protected territories in Yakutia. Collection of scientific papers, IBPK, Yakutsk, 65-69. [In Russian]

Yakovlev RV, Shapoval NA, Kuftina GN, Kulak AV, Kovalev SV (2018) Notes on the molecular taxonomy of the Proclossiana eunomia complex (Lepidoptera, Nymphalidae: Argynnini): analysis of DNA barcodes. Ukrainian Journal of Ecology 8(1): 222-232. https:// doi.org/10.15421/2018_206

Zheng B, Wang Y, Xia C, Huang D, Cao Y, Hao J, Zhu C (2018) The complete mitochondrial genome of Parnassius actius (Lepidoptera: Papilionidae: Parnassinae) with the related phylogenetic analysis. Zoological Systematics 43(1): 1-17. https://doi.org/10.11865/ zs.201801 